\title{
Soya Bean Meal and Its Extensive Use in Livestock Feeding and Nutrition
}

\author{
Yulong Yin ${ }^{1}$, Andrew A. Fatufe ${ }^{1,2}$ and Francois Blachier ${ }^{3}$ \\ ${ }^{1}$ Research Center for Healthy Breeding of Livestock and Poultry and Key \\ Laboratory for Agro-ecological Processes in Subtropical Region, Institute of \\ Subtropical Agriculture, the Chinese Academy of Sciences, 410125 Hunan \\ ${ }^{2}$ Department of Animal sciences, Obafemi Awolowo University, Ile-Ife, \\ Laboratory of Animal Nutrition and Health and Key Laboratory of \\ Subtropical Agro- ecology, Institute of Subtropical Agriculture, \\ The Chinese Academy of Sciences, Changsha, Hunan \\ 3INRA, CNRH-IdF, AgroParisTech, UMR 914 Nutrition Physiology \\ and Ingestive Behavior, 16 rue Claude Bernard, Paris, \\ ${ }^{1}$ China \\ ${ }^{2}$ Nigeria \\ ${ }^{3}$ France
}

\section{Introduction}

Soya bean (Glycine max) is an economic crop used for both human and animal feeding. Oil seed meals are important sources of protein and energy for both human and livestock. The most recent country by country estimate of global production of soya bean as at 2007 by the United States Department of Agriculture was 206.4 million tons with the US, Brazil, Argentina, China and India taking the global lead in descending order of production. Soya bean meal is mainly used as animal feed in most countries, but there is high consumption of soya bean meal as tofu in Asian countries. Soya bean has also assumed a place of importance in the production of biodiesel aimed at supplementing the world's complete dependence on fossil fuel, which is a finite resource. Soya bean meal is one of the most researched ingredients in animal nutrition and one of the most important feed ingredients used for animal feeding. There is a high demand for SBM for livestock production globally, which is driven by improvement in quality of life, a change of taste and a shift from dependence on vegetable protein to animal protein as a result of the emergence of the middle class in Asia especially in China. The recent ban on all terrestrial feed ingredients such as fish meal and bone and meat meal in pig and poultry feeding in the European Union has further tended to heavy dependence on soya bean meal as sole ingredient for nonruminant feeding. Other oil seed legumes such as peas, field beans, rapeseed seed and cotton seed meal are all measured against soya bean meal in terms of their nutritive values. The proximate and amino acid compositions of SBM and other oil seed legume are shown in Table 1. These feedstuffs are often used to substitute part of soya bean meal for animal feeding, but not to serve as complete replacement if optimum biological performance is to be attained. Most nutrients needed for the nourishment of livestock for sustenance of life, 
growth, health and reproduction are contained in feedstuff which they consume. The usefulness of a particular feed ingredient for animal feeding is not only determined by the amount of nutrient contained in it but also by the amount of 'utilisable' nutrient contained in this feed ingredient. This is often referred to as bioavailability, which is the true amount of nutrient available to the animal for productive purposes. Not all the nutrients contained in feed ingredients are available to the animal for metabolic functions. The recovery or extraction of nutrients from feed ingredients in the gastro-intestinal tract is not $100 \%$ as some of the nutrients are often lost in faeces. It is the high recovery of nutrients of soya bean

\begin{tabular}{|c|c|c|c|c|c|c|c|c|}
\hline & $\begin{array}{l}\text { Jack } \\
\text { bean } \\
\text { meal }\end{array}$ & $\begin{array}{l}\text { Field } \\
\text { bean } \\
\text { meal }\end{array}$ & $\begin{array}{l}\text { Mung } \\
\text { bean } \\
\text { meal }\end{array}$ & $\begin{array}{l}\text { Soya } \\
\text { bean } \\
\text { meal }\end{array}$ & $\begin{array}{l}\text { Rape } \\
\text { seed } \\
\text { meal }\end{array}$ & $\begin{array}{l}\text { Peanut } \\
\text { meal }\end{array}$ & $\begin{array}{l}\text { Cotton } \\
\text { seed } \\
\text { meal }\end{array}$ & $\begin{array}{l}\text { Canola } \\
\text { meal }\end{array}$ \\
\hline Dry matter & 940 & 927 & 930 & 891 & 893.0 & 830 & 936 & 932 \\
\hline $\begin{array}{l}\text { Organic } \\
\text { matter }\end{array}$ & 943 & 965 & 944 & 942 & - & - & - & - \\
\hline Crude fat & 13 & 16 & 10 & 180 & - & - & - & - \\
\hline Crude ash & 44 & 39 & 44 & 51 & 79.2 & 76 & 73 & 68 \\
\hline Calcium & 1.7 & 1.7 & 1.7 & 3.2 & - & - & - & - \\
\hline Phosphorus & 4.8 & 4.5 & 3.5 & 6.2 & - & - & - & - \\
\hline Gross energy & 17.7 & 18.3 & 17.9 & 22.6 & 20.73 & 20.75 & 18.79 & 20.0 \\
\hline NDF & 383 & 450 & 352 & 216 & 577.4 & 258 & 603 & \\
\hline $\mathrm{ADF}$ & 121 & 140 & 139 & 88 & 415.0 & 92 & 243 & \\
\hline ADL & 29 & 40 & 38 & 28 & 289.4 & 26 & 98 & \\
\hline Snsp $^{2}$ & 27 & & & 22 & 19 & 3.6 & 27 & \\
\hline ISnsp $^{3}$ & 163 & & & 167 & 153 & 106 & 231 & \\
\hline Crude protein & 205 & 272 & 286 & 412 & 414.7 & 500 & 379 & 390 \\
\hline Threonine & 6.7 & 6.1 & 6.3 & 11.8 & 12.3 & 16.3 & 11.8 & 14.1 \\
\hline Valine & 12.4 & 12.1 & 12.9 & 17.4 & 17.2 & 15.7 & 15.7 & 16.6 \\
\hline Methionine & 4.7 & 2.6 & 5.8 & 2.3 & 9.9 & 4.7 & 3.3 & 4.9 \\
\hline Isoleucine & 10.9 & 12.8 & 10.1 & 14.8 & 19.0 & 19.4 & 10.4 & 14.3 \\
\hline Leucine & 14.9 & 17.2 & 17.0 & 21.2 & 23.9 & 31.9 & 17.6 & 27.3 \\
\hline Phenyalanine & 15.2 & 15.7 & 19.1 & 14.6 & 28.4 & 23.0 & 20.5 & 14.7 \\
\hline Histidine & 7.0 & 7.9 & 6.8 & 7.4 & 11.3 & 15.4 & 10.3 & 8.5 \\
\hline Lysine & 13.0 & 12.9 & 9.4 & 20.4 & 17.8 & 20.5 & 12.9 & 18.1 \\
\hline Arginine & 16.4 & 21.5 & 15.6 & 17.8 & 20.4 & 76.6 & 37.2 & 21.9 \\
\hline Aspartic acid & 19.6 & 22.7 & 23.1 & 30.6 & 19.1 & 67.7 & 25.3 & 21.6 \\
\hline Serine & 6.7 & 7.0 & 8.4 & 14.4 & 11.0 & 25.7 & 14.4 & 14.0 \\
\hline Glutamic acid & 27.1 & 35.0 & 36.6 & 45.5 & 62.4 & 114.9 & 54.5 & 60.1 \\
\hline Glycine & 7.3 & 8.5 & 8.2 & 16.4 & 15.1 & 14.6 & 8.3 & 8.4 \\
\hline Proline & 1.8 & 2.6 & 36.6 & 16.9 & 3.2 & 4.9 & 15.9 & 20.5 \\
\hline Alanine & 7.9 & 9.1 & 9.0 & 15.8 & 14.3 & 34.0 & & \\
\hline Tyrosine & - & - & - & & 6.7 & 27.6 & 13.8 & 17.9 \\
\hline
\end{tabular}

${ }^{1}$ Results from our laboratory

${ }^{2}$ Soluble non-starch polysaccharides

${ }^{3}$ Insoluble non-starch polysaccharides

Table 1. Chemical composition of some plant protein feedstuffs (g/kg DM) ${ }^{1}$ 
meal that makes it the number one protein ingredient for pig and poultry feeding. Corn and soya bean meal are the industrial standard for feeding pigs and poultry and presumably other monogastric animal world wide. They are choice ingredients for monogastric feeding because of high level of bioavailable nutrient inherent in these feedstuffs. Most estimation of nutrient requirement based on practical type diets employed these two feed ingredients for their derivation. This high level of bioavailable nutrients in soya bean is very crucial for reducing the emission of nitrogen and phosphorus to the environment. When highly digestible nutrient are fed to pig and poultry, less nutrient are excreted and there is less concern about contamination of the environment from manure generated from livestock operations. Soya bean meal remains the single largest protein resource used for monogastric animal feeding and as such, there is the need to continually study and re-evaluate this feed ingredient, developed new SBM products, improve upon existing processing techniques and develop new methods of improving its utilisation for livestock feeding.

\section{Processing techniques and soya bean meal products}

There are different types of soya bean meal products used for animal feeding and these include solvent extracted, mechanically extracted, extruded, full fat, soya protein isolate, soya protein concentrate, soya oligosaccharides and fermented soya among others. The idea behind the various type of treatment applied to soya bean seed is to neutralise the effect of anti-nutrients present in these seeds and to improve the palatability, flavour and digestibility of soya bean meal products for animal consumption and utilisation. An indepth discussion on the various anti-nutritional factors present in soya bean seed and their effect on digestion and nutrient utilisation will be undertaken later in this chapter. Soya bean meal can be processed by dry heating, moist heating (toasting) or without heat. Proper processing (heating) of SBM is very important because under-processing will cause poor digestibility of protein and its amino acids and improper detoxification of heat labile antinutritional factors (e.g. lectins), while over heating will also result in poor protein quality from the reaction of reactive amino group of amino acids and with carbonyl group of reducing sugar also known as Maillard reaction. Lysine and cystine are the most susceptible during overheating processing of SBM and other oil seed legume seeds.

The methods of processing soya bean seed is varied depending on the intended product, level of oil expected in the product and the class of targeted livestock. Before solvent extraction, soya bean seed is cleaned, cracked, de-hulled by aspiration, heated and flaked into chips (Anonymous, 2004). Oil extraction is very efficient using hexane as the organic solvent and fat content is reduced to less than $1.0 \%$. The defatted-flake produced during the oil extraction process can be used as the starting material for other products such as soya protein concentrate (SPC) and soya protein isolate (SPI). SPC is produced by the removal of a large proportion of the $20 \%$ soluble carbohydrate fraction present in defatted soya bean flakes through leaching with water, alcohol or acid extraction. The soluble carbohydrate fraction of SBM comprise mainly of starchyose and raffinose, which are known to be responsible for off flavour taste and flatulence in man and low energy output in farm animals. The removal of the soluble carbohydrate fraction in SBM usually leads to higher crude protein (62-69\%) and crude fibre contents (3.4-4.8). To produce soya protein isolate, protein from soya flakes is made soluble by sodium hydroxide or other alkali solution and protein removed from solution by centrifugation, concentrated and spray dried (Lusas and Riaz, 1995). 
Soya bean seeds could also be extruded under pressure with steam application and under this processing method, sufficient heat for detoxification of anti-nutrient is generated. No oil is extracted and full fat soya bean meal is formed. Mechanical extraction or expeller method involved the pre-treatment of seeds such as cleaning, cracking and drying. The beans are later forced through expeller press and the oil extracted. This method have been adapted to produce improved patented product for soya bean for ruminant feeding known as SoyPLUS® which have a higher level of bypass protein of about $60 \%$ compared with the conventional production method of $35-45 \%$. By pass protein are protected proteins that are not degraded by the microbes in the rumen during extensive fermentation process, but are digested and absorbed directly in the small intestine. This type of protein are more beneficial to the ruminant animal, because the balance protein in soya bean meal will be used directly by the animals and not first diverted to microbial protein production, which is usually high in nucleic acid and not as closely related to the amino acid requirement of ruminant as soya bean protein. Solvent extracted SBM contained less oil usually less than $2 \%$, while mechanically extracted soya bean meal usually contained more residual oil (3$5 \%)$. Full fat SBM contains more oil as the name suggest and usually not less than $18 \%$. This variable oil composition also has inverse relationship with the crude protein contents of the different soya bean products and less oily product usually contained more crude protein and less metabolisable or digestible energy and vice versa. Soya bean meal is usually standardized commercially to contain $44 \%$ or $48 \%$ crude protein by addition of the hull to produce commercial low and high protein soya bean meal respectively (Pond et al., 2005). Full fat soya bean meal usually contains less crude protein of about $38-42 \%$ and a crude fibre of $3.5-4.0 \%$.

Dry heating can reduce up to $85 \%$ of antinutritional protein present in soya bean meal and also the reduction of these anti-nutrient proteins by extrusion-expeller technique may be comparable, but the efficiency of feed utilisation of broilers fed extruded soya bean meal was found to be higher than that of dry-heated soya bean meal (Vasconcelos et al., 2009). The value of extruded-expelled soya bean meal without hulls or with hulls has also be found to be similar to that of solvent extracted soya bean meal with or without hull added, but was found to be higher than that of extruded-expelled soya bean meal produced for ruminant feeding with high level of by pass protein (Woodworth et al., 2001). The soya bean meal with high by pass protein was less efficiently utilised when fed to young pigs and was characterised with poorer average daily gain and gain to feed ratio. This goes further to buttress the fact that, the choice of which soya bean product to feed should be determined by the class of animals to which product is to be fed and the prevailing prices of other soya bean meal product in the market. Another factor that may affect the feeding value of soya bean meal for farm animals is the location of production, because yield/hectare is known to be inversely related to protein content in soya bean seeds. The proximate and amino acid compositions of the different SBM products are shown in Table 2.

Purified products from soya bean seeds such as oligosaccharides and water soluble polysaccharides have been reported to have health benefits when fed to poultry and pigs. Soya bean seeds contain oligosaccharides in form of sucrose, raffinose and stachyose, which are non-reducing sugars made up of fructose, glucose and galactose and may account for up to $5 \%$ of the dry weight of the seed (Espinosa-Martos and Rupérez, 2006). Raffinose and stachyose are a-linked oligosaccharides (galactooligosaccharides) which are non-digestible carbohydrate for pigs and poultry and therefore transit through the gastrointestinal tract to large intestine (colon), where they are metabolised by microbes that are capable of producing a-galactosidase 
needed for galactose metabolism. The metabolism of these oligosaccharides results in production of methane, carbon dioxide, hydrogen and volatile fatty acids and therefore are said to function as prebiotics. Reports from animal experiments have shown that these isolated products from soya bean seeds are effective as prebiotics and these products have also found wider application in human nutrition and are known as functional foods. It was observed in broilers that, soya bean meal oligosaccharides and water soluble polysaccharides promoted the growth of lactic acid bacteria communities in the caecum and had competitive exclusion function when chicken was infected with Eimera tenella (Lan et al., 2004). Other interesting compound in soya bean flour includes isoflavones or phytoestrogen, which are anti-oxidants (polyphenols) which have shown promise in preventing the spread of breast and prostrate cancer in human.

\begin{tabular}{lllllll}
\hline & $\begin{array}{l}\text { Raw } \\
\text { SBM }\end{array}$ & $\begin{array}{l}\text { Heated } \\
\text { SBM }^{2}\end{array}$ & $\begin{array}{l}\text { Steamed } \\
\text { SBM }^{3}\end{array}$ & $\begin{array}{l}\text { Solvent } \\
\text { extracted } \\
\text { SBM }\end{array}$ & $\begin{array}{l}\text { Protein } \\
\text { isolate }\end{array}$ & $\begin{array}{l}\text { Protein } \\
\text { concentrat } \\
\mathrm{e}^{4}\end{array}$ \\
\hline Dry matter & 895 & 960 & 890 & 894.7 & 920 & 900 \\
Ash & 57 & 58 & 57 & 75.3 & - & - \\
Gross energy & 22.59 & 22.60 & 22.98 & 21.2 & & - \\
ADF & 88 & - & - & 115.5 & - & - \\
NDF & 216 & - & - & 352.0 & - & - \\
ADL & 28 & - & - & 42.0 & - & - \\
Crude protein & 412 & 413 & 411 & 496.3 & 858 & 640 \\
Threonine & 11.8 & 11.7 & 11.6 & 20.3 & 31.7 & 28.0 \\
Valine & 17.4 & 17.5 & 17.3 & 24.8 & 42.1 & 34.0 \\
Methionine & 2.0 & 2.0 & 1.9 & 5.1 & 10.1 & 9.0 \\
Isoleucine & 14.8 & 14.7 & 14.9 & 20.0 & 42.5 & 33.0 \\
Leucine & 21.2 & 21.2 & 21.1 & 33.8 & 66.4 & 53.0 \\
Phenyalanine & 14.6 & 14.7 & 14.5 & 25.0 & 43.4 & 34.0 \\
Histidine & 7.4 & 7.4 & 7.3 & 15.7 & 22.5 & 18.0 \\
Lysine & 20.4 & 20.5 & 20.3 & 30.3 & 52.6 & 42.0 \\
Arginine & 17.8 & 17.7 & 17.8 & 37.1 & 68.7 & 57.9 \\
Aspartic acid & 30.6 & 30.7 & 30.5 & 61.2 & - & - \\
Serine & 14.4 & 14.4 & 14.4 & 24.2 & - & - \\
Glutamic acid & 45.5 & 45.5 & 45.0 & 62.7 & - & - \\
Proline & 16.9 & 16.7 & 16.6 & 21.1 & - & - \\
Glycine & 16.4 & 16.4 & 16.0 & 23.3 & - & - \\
Alanine & 15.8 & 15.9 & 15.7 & 22.9 & - & - \\
Tyrosine & 7.4 & 7.5 & 7.2 & 12.8 & 25.0 & 18.2 \\
\hline Resuts fran & & & & & & \\
\hline
\end{tabular}

1 Results from our laboratory

2 Subjected to $105^{\circ} \mathrm{C}$ for $30 \mathrm{~min}$ in an oven.

${ }^{3}$ Steamed at $0.1 \mathrm{MPa}$ for $30 \mathrm{~min}$ in an autoclave.

${ }^{4}$ Adapted from NRC 1998 (SPI and SPC)

Table 2. Chemical compositions of soya bean meal products ${ }^{1}$

\section{Amino acid composition and digestibility of soya bean meal}

Soya bean meal contained highly digestible amino acid content for pig and poultry. Various terminologies are often employed in the description of digestibility in non-ruminant animal 
nutrition. These terminologies are often related to site at which measurement was made and whether correction has been made for endogenous contribution or not. Not all the protein and other nutrients found in faeces and urine are from the feed, but some are from digestive secretions and sloughing off of the gastro-intestinal tissues (from digestive tract itself). Two endogenous sources are known at present which are those caused by the level of dry matter intake and animal factors known as basal endogenous loss and the one caused by the feed component which is known as specific endogenous losses. Due to difficulty involved in the measurement of specific endogenous losses (by isotope dilution technique), only basal endogenous losses is mostly measured in feed ingredient for pigs and poultry. When correction is made for basal and specific endogenous sources, digestibility values are said to be true (standardized) and real respectively, whereas when no correction has been made, digestibility values are said to be apparent.

There are also considerable microbial activities in the hind gut of poultry and pig (more activity in pig than poultry) due to microbial fermentation. These microbial activities usually lead to microbial protein synthesis, production of volatile fatty acids and other metabolites which are not available to the non-ruminant animals for absorption because this region has gone past the region of the small intestine where most of the nutrient absorption takes place. Therefore most animal nutritionists are of the opinion that the measurement of protein in faeces may be misleading and may not be a true picture of what was absorbed and the idea is therefore to make measurement at the end of the small intestine (distal ileum), where absorption is thought to be completed. Both ileal and faecal measurements can be described as apparent and true digestibility depending on if correction was made for endogenous contribution or not. True digestibility is often higher than apparent digestibility especially in high protein ingredients used commonly for pig and poultry feeding and similarly, ileal measurements are often higher than measurements made in the faeces for the same set of ingredients. The apparent ileal amino acid digestibility for swine is above $75 \%$ for amino acids lysine, methionine, threonine and tryptophan. These are very important amino acids because, these are the amino acid likely to be deficient in the ration of pigs and poultry based on common ingredients (corn-soya bean) used for poultry and swine ration formulation. The true faecal amino acid digestibility of the essential amino acids contained in soya bean meal for poultry is on the average higher than $85 \%$. We have extensively characterised soya bean products and other protein sources commonly used for swine and poultry feeding for their chemical composition and digestible nutrient contents using the various digestibility techniques in our laboratory (Yin et al., 1991; Yin et al., 1993a; Yin et al., 1993b; Yin 1994; Yin et al., 1994; Yin et al., 2008). The apparent and standardized ileal digestibility coefficients of SBM products and other plant protein sources are presented in Tables 3-6. However, soya bean meal is deficient in sulphur amino acids (methionine and cysteine) and this is the first limiting amino acid in corn-soya bean meal for poultry. Synthetic methionine source (DL- methionine or methionine hydroxy analogue) is usually added to poultry diet to alleviate this deficiency of sulphur amino acids. The order of limiting amino acids in corn-soya bean meal diet for pigs is lysine, methionine, threonine and tryptophan, while that of poultry is methionine, lysine, threonine and tryptophan.

\section{Anti-nutritional factors in soya bean meal}

Soya bean meal like most other oil seed meal contain antinutritional factors such as protease inhibitors, phytic acid, allergens, lectins, saponins, antivitamins and phytoestrogens, which are 
chemical substances used by plants for self defence against invasion of disease causing or foreign organism. These anti-nutritional factors mediate their effect in farm animals by reducing protein digestibility, toxicity, binding with nutrients and causing precipitations or producing un-absorbable chemical forms (unusable) and may negatively impair the development of the gastro-intestinal tract in young animals. Protease inhibitors (trypsin inhibitor) and lectin (haemagglutinin) have a negative effect on digestion, absorption, efficiency of utilisation and metabolism of protein and growth rate in simple stomach farm animals fed on raw or poorly processed (undercooked) soya bean meal. The presence of protease inhibitors often results in hypertrophy of the pancreas from over stimulation of this organ to increase gastric secretions. The protease inhibitors which can constitute as much as $6 \%$ of protein in soya bean seed can be classified into the heat labile Kunitz trypsin fraction and Bowman-Birk heat stable protease inhibitor fraction (Francis et al., 2001). The heat labile fraction is readily inactivated and its influence drastically reduced when soya bean meal is subjected to heat treatment. Their influences are more prominent, when raw unprocessed soya bean are fed to pigs and poultry. Moist heat treatments such cooking and steaming are most effective in inactivation or destruction of protease inhibitors and lectin in soya bean seeds.

\begin{tabular}{|c|c|c|c|c|c|c|c|}
\hline & $\begin{array}{l}\text { Dry } \\
\text { matter }\end{array}$ & $\begin{array}{l}\text { Organic } \\
\text { matter }\end{array}$ & $\begin{array}{l}\text { Gross } \\
\text { energy }\end{array}$ & ADF & NDF & ADL & $\begin{array}{l}\text { Crude } \\
\text { protein }\end{array}$ \\
\hline Raw SBM & 81 & 85 & 80 & 31 & 52 & - & 59 \\
\hline Heated SBM & 86 & 88 & 85 & - & - & - & 67 \\
\hline Steamed SBM & 86 & 88 & 87 & - & - & - & 68 \\
\hline SBM & 88 & 90 & 91 & - & - & - & 87 \\
\hline RSM & 84 & 85 & 82 & 32 & 41 & 22 & 66 \\
\hline PNM & 87 & 88 & 88 & 40 & 44 & 26 & 87 \\
\hline CSM & 74 & 77 & 76 & 38 & 46 & 26 & 73 \\
\hline Jack bean ${ }^{2}$ & 84 & 85 & 85 & 16 & 64 & 9 & 54 \\
\hline Jack bean ${ }^{3}$ & 84 & 84 & 84 & - & - & - & 56 \\
\hline Field beans ${ }^{2}$ & 88 & 89 & 88 & 15 & 66 & 14 & 83 \\
\hline Field beans ${ }^{3}$ & 82 & 84 & - & - & - & - & 71 \\
\hline Peas $^{2}$ & 90 & 91 & 90 & 35 & 73 & 29 & 85 \\
\hline Peas $^{3}$ & 83 & 85 & 85 & - & - & - & 70 \\
\hline Mung bean ${ }^{2}$ & 86 & 88 & 86 & 25 & 64 & 32 & 74 \\
\hline Mung bean ${ }^{3}$ & 90 & 92 & 89 & - & - & - & 80 \\
\hline
\end{tabular}

${ }^{1}$ Results from our laboratory

${ }^{2}$ Raw form

${ }^{3}$ Steamed at $0.1 \mathrm{MPa}$ for $30 \mathrm{~min}$ in an autoclave.

Table 3. Apparent Ileal digestibility of soya bean meal and other plant proteins feedstuffs in pigs (proximate constituents) ${ }^{1}$

Evidence from previous studies with chicks revealed that about $15 \%$ of growth depression from protease inhibitors is from the effect of lectin (Douglas et al., 1999). This deduction was made on the basis that raw lectin-free soya bean meal had a higher nutritive value than raw soya bean meal, but less value compared kunitz trypsin inhibitors free soya bean meal, implying that trypsin inhibitor may be more toxic than the lectins, but the nutritive value of raw lectin-free and kunitz-trypsin free SBM is lower to that of heat treated SBM (Batal and Parson, 2003). Soya bean meal samples with less trypsin inhibitor content and higher crude protein content have been reported to result in better digestibility of gross energy, nitrogen and amino acids in young broilers (Coca-Sinova et al., 2008). Phytate and antivitamins (e.g. 
antivitamins A, D, E, K, thiamine, riboflavin, pyridoxine and B12) affect mineral and vitamin utilisation in non-ruminant animals fed untreated soya bean meal. A large proportion of the phosphorus present in plant $(60-80 \%)$ is in a complex form of myoinositol hexaphosphate (Phytate). Pigs, poultry and other non-ruminant animals do not possess the digestive enzyme (phytase) in their gastrointestinal tracts that is needed to break down phytate and invariably most of the phosphorus in soya bean meal passes through the tract unused and is excreted in the manure. As a consequence of the poor digestibility, supplemental phosphorus was usually added to the diets of non-ruminant animals to meet the dietary requirements for optimal growth rate. There has been an outcry from the society to reduce phosphorus and nitrogen to the environment from livestock industry in the past years due to the adverse effect on the environment such as eutrophication of water bodies and contamination of ground water by excessive application of animal manure as fertiliser. The runoff from this fertiliser application has been implicated in destruction of aquatic ecosystem through algal blooms; depletion of oxygen and death of aquatic species. Swine manure has the largest concentration of phosphorus because of the addition of inorganic phosphorus in an attempt to supplement the non-digestible phytate.

\begin{tabular}{|c|c|c|c|c|c|c|c|c|c|c|c|c|c|c|c|c|}
\hline & Thr & Val & Met & Iso & Leu & Phe & His & Lys & Arg & Asp & Ser & Glu & Pro & Gly & Ala & Tyr \\
\hline$\overline{\text { Raw SBM }}$ & 58 & 61 & 68 & 62 & 58 & 56 & 66 & 57 & 67 & 64 & 62 & 68 & 57 & 63 & 60 & 55 \\
\hline $\begin{array}{l}\text { Heated } \\
\text { SBM }\end{array}$ & 76 & 66 & 62 & 76 & 70 & 73 & 75 & 77 & 89 & 83 & 81 & 83 & 84 & 70 & 70 & 75 \\
\hline $\begin{array}{l}\text { Steamed } \\
\text { SBM }\end{array}$ & 79 & 78 & 69 & 73 & 80 & 80 & 76 & 80 & 90 & 84 & 84 & 87 & 66 & 76 & 74 & 82 \\
\hline SBM & 83 & 85 & 85 & 87 & 87 & 87 & 88 & 86 & 94 & 89 & 85 & 89 & 84 & 83 & 82 & 82 \\
\hline SPI2 & 90 & 86 & - & 90 & 92 & 88 & 88 & 88 & 91 & - & - & - & - & - & - & 89 \\
\hline $\mathrm{SPC}^{2}$ & 85 & 91 & 91 & 93 & 93 & 94 & 95 & 93 & 97 & - & - & - & - & - & - & 93 \\
\hline RSM & 72 & 73 & 83 & 76 & 76 & 74 & 80 & 72 & 78 & 72 & 74 & 82 & 68 & 72 & 70 & 66 \\
\hline PNM & 79 & 60 & 75 & 75 & 73 & 80 & 80 & 76 & 92 & 89 & 85 & 90 & 47 & 84 & 76 & 86 \\
\hline CSM & 66 & 67 & 72 & 68 & 70 & 79 & 70 & 50 & 86 & 71 & 69 & 91 & 69 & 68 & 62 & 69 \\
\hline $\begin{array}{l}\text { Jack } \\
\text { bean }^{3}\end{array}$ & 52 & 33 & 36 & 31 & 41 & 34 & 54 & 54 & 35 & 52 & 53 & 58 & 34 & 34 & 34 & - \\
\hline $\begin{array}{l}\text { Jack } \\
\text { bean } 4\end{array}$ & 66 & 58 & 60 & 62 & 61 & 70 & 57 & 72 & 75 & 69 & 74 & 71 & 59 & 57 & 54 & - \\
\hline $\begin{array}{l}\text { Field } \\
\text { beans }^{3}\end{array}$ & 74 & 75 & 65 & 79 & 81 & 71 & 86 & 85 & 89 & 84 & 81 & 88 & 84 & 65 & 74 & - \\
\hline $\begin{array}{l}\text { Field } \\
\text { beans }{ }^{4}\end{array}$ & 71 & 72 & - & 65 & 77 & 66 & 58 & 80 & 91 & 82 & 77 & 86 & - & 66 & 71 & 64 \\
\hline $\begin{array}{l}\text { Mung } \\
\text { bean }^{3}\end{array}$ & 78 & 77 & 63 & 69 & 80 & 76 & 76 & 73 & 70 & 82 & 86 & 86 & 67 & 63 & 73 & - \\
\hline $\begin{array}{l}\text { Mung } \\
\text { bean }{ }^{4}\end{array}$ & 77 & 79 & 77 & 74 & 80 & 85 & 82 & 89 & 88 & 86 & 86 & 89 & 79 & 80 & 76 & 74 \\
\hline Peas $^{3}$ & 81 & 89 & 77 & 81 & 83 & 81 & 82 & 81 & 87 & 88 & 88 & 92 & 77 & 77 & 84 & 83 \\
\hline Peas 4 & 80 & 82 & 78 & 73 & 80 & 70 & 71 & 86 & 93 & 83 & 83 & 91 & 70 & 75 & 81 & 88 \\
\hline
\end{tabular}

${ }^{1}$ Results from our laboratory

${ }^{2}$ Adapted from NRC 1998

${ }^{3}$ Raw form

${ }^{4}$ Steamed at $0.1 \mathrm{MPa}$ for $30 \mathrm{~min}$ in an autoclave.

Table 4. Apparent Ileal digestibility of soya bean meal products and selected plant proteins feedstuffs in pigs (amino acids) ${ }^{1}$ 


\begin{tabular}{|c|c|c|c|c|c|c|c|c|c|c|}
\hline & $\begin{array}{l}\mathrm{CP} \\
(\mathrm{PF})\end{array}$ & $\begin{array}{l}\mathrm{CP} \\
(\mathrm{EHC})\end{array}$ & $\begin{array}{l}\text { Arg } \\
\text { (PF) }\end{array}$ & $\begin{array}{l}\text { Arg } \\
\text { (EHC) }\end{array}$ & $\begin{array}{l}\text { His } \\
\text { (PF) }\end{array}$ & $\begin{array}{l}\text { His } \\
\text { (EHC) }\end{array}$ & $\begin{array}{l}\text { Ile } \\
(\mathrm{PF})\end{array}$ & $\begin{array}{l}\text { Ile } \\
\text { (EHC) }\end{array}$ & $\begin{array}{l}\text { Leu } \\
\text { (PF) }\end{array}$ & $\begin{array}{l}\text { Leu } \\
\text { (EHC) }\end{array}$ \\
\hline Raw SBM & 61 & 63 & 68 & 69 & 68 & 69 & 64 & 65 & 60 & 61 \\
\hline $\begin{array}{l}\text { Heated } \\
\text { SBM }\end{array}$ & 69 & 71 & 90 & 91 & 77 & 78 & 78 & 79 & 72 & 73 \\
\hline $\begin{array}{l}\text { Steamed } \\
\text { SBM }\end{array}$ & 70 & 72 & 91 & 92 & 78 & 79 & 75 & 76 & 82 & 83 \\
\hline $\begin{array}{l}\text { Soya-bean } \\
\text { meal I (501 } \\
\text { g kg-1 DM) }\end{array}$ & 84 & 85 & 82 & 82 & 86 & 87 & 83 & 83 & 80 & 81 \\
\hline $\begin{array}{l}\text { Soya-bean } \\
\text { meal II (477 } \\
\text { g kg-1 DM) }\end{array}$ & NA & NA & 95 & 95 & 89 & 89 & 91 & 92 & 89 & 89 \\
\hline $\begin{array}{l}\text { Soya-bean } \\
\text { meal III } \\
(511 \text { g kg-1 } \\
\text { DM) }\end{array}$ & 89 & 90 & 95 & 96 & 89 & 90 & 86 & 87 & 88 & 90 \\
\hline Jack bean ${ }^{2}$ & 59 & 62 & 37 & 38 & 56 & 57 & 34 & 35 & 43 & 44 \\
\hline Jack bean ${ }^{3}$ & 61 & 64 & 77 & 78 & 59 & 60 & 65 & 66 & 63 & 65 \\
\hline $\begin{array}{l}\text { Field } \\
\text { beans² }\end{array}$ & 87 & 89 & 90 & 91 & 88 & 89 & 82 & 82 & 83 & 85 \\
\hline $\begin{array}{l}\text { Field } \\
\text { beans }{ }^{3}\end{array}$ & 75 & 77 & 92 & 93 & 60 & 61 & 68 & 68 & 79 & 81 \\
\hline $\begin{array}{l}\text { Mung } \\
\text { bean }^{2}\end{array}$ & 78 & 79 & 72 & 73 & 78 & 80 & 72 & 73 & 82 & 84 \\
\hline $\begin{array}{l}\text { Mung } \\
\text { bean }^{3}\end{array}$ & 84 & 85 & 90 & 91 & 84 & 86 & 77 & 78 & 82 & 84 \\
\hline Peas $^{2}$ & 89 & 91 & 88 & 89 & 85 & 87 & 83 & 84 & 86 & 87 \\
\hline Peas $^{3}$ & 74 & 76 & 95 & 97 & 74 & 76 & 75 & 76 & 83 & 84 \\
\hline
\end{tabular}

${ }^{1}$ Results from our laboratory

2 Raw form

${ }^{3}$ Steamed at $0.1 \mathrm{MPa}$ for $30 \mathrm{~min}$ in an autoclave.

Table 5. Standardized essential amino acid ileal digestibility of soya bean products and other plant protein sources determined by protein-free (PF) or enzyme-hydrolyzed casein (EHC) methods in growing pigs ${ }^{1}$

The advance in breeding techniques has led to identification of the gene responsible for phytate in soya bean and this has led to the breeding of low phytate soya bean by blocking the synthesis of phytate through the use of mutant genes without any loss in yield and the amount of phosphorus present in soya bean. Phytate can be rendered more digestible through heat treatment or through the supplementation of phytase in feed of non-ruminant animals. The anti-vitamins interfere with the absorption and/or metabolism of their respective vitamins, but most are readily destroyed by moist heat treatment used for processing of soya bean meal. Sucrose, raffinose and stachyose are the main a-linked oligosaccharides in soya bean meal. These oligosaccharides and other water soluble polysaccharides are also known to be anti-nutrient when present in soya bean meals 
products, because they cause flatulence, muscular cramps, diarrhoea, reduce the true metabolisable energy and fibre digestion in non-ruminant animals, whereas isolated products of these polysaccharides have also found application in functional food in animal and human nutrition as a prebiotics.

\begin{tabular}{|c|c|c|c|c|c|c|c|c|c|c|}
\hline & $\begin{array}{l}\text { Lys } \\
\text { (PF) }\end{array}$ & $\begin{array}{l}\text { Lys } \\
\text { (EHC) }\end{array}$ & $\begin{array}{l}\text { Met } \\
(\mathrm{PF})\end{array}$ & $\begin{array}{l}\text { Met } \\
\text { (EHC) }\end{array}$ & $\begin{array}{l}\text { Phe } \\
\text { (PF) }\end{array}$ & $\begin{array}{l}\text { Phe } \\
\text { (EHC) }\end{array}$ & $\begin{array}{l}\text { Thr } \\
\text { (PF) }\end{array}$ & $\begin{array}{l}\text { Thr } \\
\text { (EHC) }\end{array}$ & $\begin{array}{l}\text { Val } \\
(\mathrm{PF})\end{array}$ & $\begin{array}{l}\text { Val } \\
\text { (EHC) }\end{array}$ \\
\hline Raw SBM & 59 & 60 & 73 & 81 & 58 & 59 & 62 & 64 & 63 & 65 \\
\hline $\begin{array}{l}\text { Heated } \\
\text { SBM }\end{array}$ & 79 & 80 & 67 & 75 & 75 & 76 & 80 & 82 & 68 & 70 \\
\hline $\begin{array}{l}\text { Steamed } \\
\text { SBM }\end{array}$ & 82 & 83 & 74 & 82 & 82 & 83 & 83 & 85 & 80 & 82 \\
\hline $\begin{array}{l}\text { Soya-bean } \\
\text { meal I }\end{array}$ & 86 & 87 & 78 & 82 & 80 & 81 & 80 & 81 & 78 & 79 \\
\hline $\begin{array}{l}\text { Soya-bean } \\
\text { meal II }\end{array}$ & 87 & 88 & 91 & 95 & 88 & 89 & 88 & 89 & 91 & 92 \\
\hline $\begin{array}{l}\text { Soya-bean } \\
\text { meal III }\end{array}$ & 87 & 88 & 81 & 91 & 88 & 89 & 83 & 84 & 81 & 82 \\
\hline Jack bean ${ }^{2}$ & 56 & 58 & 47 & 67 & 36 & 37 & 59 & 62 & 59 & 76 \\
\hline Jack bean ${ }^{3}$ & 74 & 76 & 70 & 88 & 72 & 73 & 73 & 76 & 88 & 107 \\
\hline $\begin{array}{l}\text { Field } \\
\text { beans }{ }^{2}\end{array}$ & 88 & 89 & 68 & 75 & 72 & 73 & 83 & 86 & 78 & 81 \\
\hline $\begin{array}{l}\text { Field } \\
\text { beans }^{3}\end{array}$ & 83 & 84 & NA & NA & 68 & 69 & 80 & 84 & 76 & 78 \\
\hline $\begin{array}{l}\text { Mung } \\
\text { bean }^{2}\end{array}$ & 77 & 79 & 65 & 67 & 77 & 78 & 86 & 90 & 80 & 82 \\
\hline $\begin{array}{l}\text { Mung } \\
\text { bean }^{3}\end{array}$ & 93 & 95 & 79 & 81 & 86 & 87 & 86 & 90 & 82 & 84 \\
\hline Peas $^{2}$ & 84 & 85 & 83 & 94 & 83 & 85 & 89 & 92 & 94 & 97 \\
\hline Peas $^{3}$ & 89 & 91 & 84 & 96 & 72 & 74 & 88 & 92 & 87 & 90 \\
\hline
\end{tabular}

${ }^{1}$ Results from our laboratory

${ }^{2}$ Raw

${ }^{3}$ Steamed at $0.1 \mathrm{MPa}$ for $30 \mathrm{~min}$ in an autoclave.

Table 5. continued. Standardized ileal digestibility of crude protein and essential amino acid of soya bean products and other plant protein sources determined by protein-free (PF) or enzyme-hydrolyzed casein (EHC) methods in growing pigs $^{1}$

\begin{tabular}{lllll}
\hline & Lys & Met & Thr & Trp \\
\hline Amino acid (\%) & 2.98 & 0.69 & 1.89 & 0.61 \\
Digestibility coefficient & 91 & 93 & 90 & - \\
Digestible amino acid (\%) & 2.71 & 0.64 & 1.70 & - \\
\hline
\end{tabular}

${ }^{1}$ Adapted from Aminodat 1.1, Degussa AG, Germany.

Table 6. Standardized ileal digestibility of soya bean meal $(48 \% \mathrm{CP})$ in poultry ${ }^{1}$

These antinutritional factors have similar effect when they are found in notable amounts in other feedstuffs especially oil seed legumes and are not limited to soya bean seeds alone. Readers are referred to the reviews on antinutritional factors in oil seed meal of Francis et al. 
(2001) and Tacon (1997) for in-depth study of the subject matter. The effect of moist heat treatment on trypsin inhibitors, urease activity and FDNB- available in soya bean is presented in Table 7.

\begin{tabular}{llllll}
\hline Time (minutes) & 0 min. & 5 min. & 10 min. & 15 min. & 25 min. \\
\hline Urease index & 2.18 & 0.00 & 0.00 & 0.00 & 0.00 \\
Trypsin inhibitors (mg/g) & 20.04 & 2.19 & 2.28 & 1.58 & 1.52 \\
FDNB-available lysine 2 & 27.80 & 23.53 & 19.52 & 17.68 & 18.10 \\
\hline
\end{tabular}

${ }^{1}$ From our laboratory

2 2, 4-dinitro-fluorobenzene and the free-amino acid group of lysine

Table 7. Influence of autoclaving time at $125 \mathrm{C}$ and $0.1 \mathrm{MPa}$ pressure on the urease activity, trypsin inhibitors and FDNB-available lysine content $\left(\mathrm{g} / \mathrm{kg}\right.$ DM) in raw SBM${ }^{1}$

As shown in Table 1, the beans list in the table all of them contains non-starch polysaccharide (NSP). Recently, we found that the $\mathrm{N}$ in ileal digesta or feces have been found mainly from the endogenous microorganisms $\mathrm{N}$ (Fig. 1). Endogenous $\mathrm{N}$ losses, especially those related to microorganisms, in ileal digesta and feces were found to be the major reasons of low efficiency of dietary protein and environmental pollution of $\mathrm{N}$ in the pig industry. Further studies we have found that the soluble NSP, rather than the insoluble NSP, is the main factor that causes endogenous N secretion. However, using of the soluble NSP enzyme can improves pig performance through the degradation of soluble NSP in the intestine of pigs and by reducing the loss of endogenous AAs in the small intestine in pigs (Yin et al., 2000a,b; Yin et al., 2001a,b ;Yin and Tan, 2010).

Yin YL and Tan BE, Manipulation of dietary nitrogen, amino acids and phosphorus to reduce environmental impact of swine production and enhance animal health. Journal of Food, Agriculture \& Environment. 8: 447-462 (2010).

\section{In vitro quality assessment of soya bean meal products for livestock feeding}

Three standard methods are routinely used for the in-vitro assessment of the protein quality of SBM for livestock feeding. These include urease test, protein dispersibility index (PDI) and protein solubility methods. Protein dispersibility index and protein solubility are hinged on the solubility of SBM in water and alkali respectively. Soya bean meal product is usually added to water or potassium hydroxide solution and centrifuged over a period of time and the amount of dissolved nitrogen determined in the supernatant. PDI or protein solubility is then expressed as the percentage of the protein present in the initial dry soya bean product. Over-heating of SBM during processing is known to depress the values of 
both indices. Urease index which is used to determine residual activity of antinutritional factors in heat treated SBM by observing $\mathrm{pH}$ increase. This is used as an indicator for the detoxification of heat labile anti-nutritional factors in processed SBM especially trypsin inhibitor and lectins. This is based on the fact that these heat labile antinutritional factors are more readily inactivated by heat than urease, which is more heat tolerant, but its use may be limited in detecting overcooking in SBM products. The solubility of soya protein in potassium hydroxide for adequately processed SBM product ranged from $70-85 \%$, while higher solubility often indicate lack of or inadequate heat processing and values below the lower threshold often portends excessive heat processing (Araba and Dale, 1990a\&b; Lusas and Riaz, 1995; Batal et al., 2000).

\section{Use of soya bean meal in non-ruminant animal}

Corn-soya bean meal is the industrial standard for feeding pigs and poultry world wide. The inclusion level of soya bean meal and the type of soya bean meal product fed to nonruminant animal varied, depending on the breeding objective of the livestock enterprise. The inclusion rate of soya bean product in the feed of various categories of non-ruminant animals will vary depending on the crude protein requirement of the target specie. Starting broilers have a crude protein requirement of $23 \%$, while growing pigs have crude protein requirement of $18-20 \%$, therefore theoretically, since soya bean meal can supply all the protein need along with corn, the inclusion level of soya bean meal in the diet of broiler should be higher than that of growing pigs. It is a common practice for soya bean meal to be used as the sole source of protein alongside with corn especially in diets of young non-ruminant animals. The choice of product to be fed is also dependent on the rearing objective. For instance, full fat soya is a good choice of feeding broilers and weanling pigs due to their high energy requirements, but may not be a choice product for feeding laying hen and gilts due to its high fat content and the tendency for these animals to deposit extra energy in form of fat that may interfere with their reproductive performance. It is a well known fact that fat deposition is directly related the amount of fat present in the diet. However, the decision on how much of a particular ingredient to include in the ration of animal is not only a biological decision, but also an economic decision, because the objective of farming enterprise is foremost to maximise profit, and the level of biological performance at which profit can be maximised may not necessarily be the highest level of performance. Therefore the level of inclusion of these products in non-ruminant feeding is not static, but is driven by cost of other ingredients available for ration formulation, which can serve as partial replacement for these soya bean meal products, and the level at which animals are expected to perform or the intended target weight or performance level expected from a stock. This is known as least cost ration formulation for livestock, in which farm animals are furnished with the required nutrient at the most economic rate using a combination of ingredients to achieve this. Technically, farm animals have no need for any specific ingredient, but can thrive on a combination of ingredients provided this is skilfully combined to provide the needed nutrients based on the knowledge of nutrient requirement of the animal for the particular set of nutrients, bioavailability of nutrients from the sources combined, price of various ingredients and the biology of the animal in question. Soya bean meal however, has a comparative 
advantage over other protein ingredient for farm animal feeding due to its amino acid composition and high level of bioavailability of its amino acid.

Use in pre-ruminant and ruminant feeding

\section{Microbial N Other N}

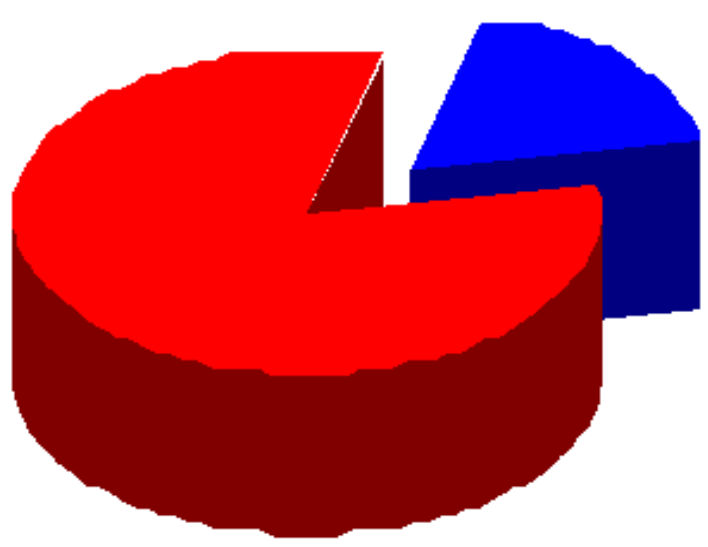

Fig. 1. Faeces $\mathrm{N}$ compistion

Soya bean meal is known to contain allergenic or antigenic factors such as a-conglycinin, and $\beta$-conglycinin which are known to trigger specific and non-specific immune response in several farm animals, but especially in a large proportion of pre-ruminant calves (Sisson, 1982). The feeding of soya bean products in some pre-ruminant calves were linked with intolerance, reduction in digesta transit time, vomiting and diarrhoea, failure of immunodefence mechanism of the gut, low secretion of immunoglobulins such IgA and IgM against soya bean antigens, and rapid loss of weight. The presence of $\beta$-conglycinin in soya bean meal depressed digestibility in young calves and has more potent depressive effect on protein digestibility than trypsin inhibitor (Lalles et al., 1995). However, these immunologically active globulins were not detected in soya protein concentrate produced by leaching with aqueous alcohol, implying their inactivation. Similarly, pre-ruminant calves just like their non-ruminant counterparts have no digestive enzymes for soya 
oligosaccharides sucrose, raffinose and starchyose and these oligosaccharides are known to produce similar effect in pre-ruminant calves as they do in non-ruminant counterparts. However, these oligosaccharides are eliminated during the leaching process for the production of SPI and this makes SPI the most suitable SBM product for feeding preruminant calves.

\section{Conclusion}

Due to the high demand for soya bean meal and its products for livestock feeding, which is set to continue in the future, there is therefore the need to continue to research many ways of improving the efficiency of nutrients utilization in SBM. The area of interest for animal nutritionists will how to improve processing methods and to develop new products that will be suitable for various classes of livestock, reduce the indigestible carbohydrate content, minimise residual anti-nutritional factors and improve nutrient digestibility, which is the main determinant of nutrient availability to livestock species.

\section{References}

Anonymus 2004. Soybean meal processing http://www.soyplus.com/bulletins.asp accessed on $22 / 11 / 2010$

Araba, M., N. M. Dale (1990a). Evaluation of protein solubility as an indicator of overprocessing soybean meal. Poult. Sci. 69, 76-83.

Araba, M. and N. M. Dale (1990b). Evaluation of protein solubility as an indicator of underprocessing of soybean meal. Poult. Sci. 69, 1749-1752.

Batal A. B. and C. M. Parsons (2003). Utilization of different soy products as affected by age in chicks. Poult Sci. 82:454-462

de Coca-Sinova A., D. G. Valencia,E. Jiménez-Moreno,R. L醶aro and G. G. Mateos (2008). Apparent Ileal Digestibility of Energy, Nitrogen, and Amino Acids of Soybean Meals of Different Origin in Broilers Poultry Science 87:2613-2623 doi:10.3382/ps.2008-00182

Douglas, M. W., C. M. Parsons and T. Hymowitz (1999). Nutritional evaluation of lectin-free soybeans for poultry. Poult. Sci. 78:91-95.

Espinosa-Martos I. and P. Rupérez (2006). Soybean oligosaccharides. Potential as new ingredients in functional food. Nutr Hosp. 21(1):92-6

Francis G., H. P.S. Makkar, K. Becker (2001). Antinutritional factors present in plantderived alternate fish feed ingredients and their effects in fish Aquaculture 199: 197-227

Lan Y., B.A. Williams, M.W.A. Verstegen, R. Patterson and S. Tamminga (2007). Soy oligosaccharides in vitro fermentation characteristics and its effect on caecal microorganisms of young broiler chickens Animal Feed Science and Technology 133: 286-297

Lan, Y., S. Xun, S. Tamminga, B. A. Williams, M. W. A. Verstegen, and G. Erdi (2004). RealTime PCR detection of lactic acid bacteria in cecal contents of Eimeria tenellaInfected broilers fed soybean oligosaccharides and soluble soybean polysaccharides. Poultry Science 83:1696-1702 
Lalles J.P., H.M. Tukur, R. Toullec and B.G. Miller (1996). Analytical criteria for predicting apparent digestibility of soybean protein in preruminant calves. Journal of Dairy Science 79: 475-482 Abstract access this article

Lusas E. W. and M. N. Riaz (1995). Soy Protein Products: Processing and use J. Nutr. 125: 573S-580S

Pond WG, DC Church, KR Pond et al. (2005). Basic animal nutrition and feeding. Fifth edition. John Wiley \& Sons, Inc, Danvers, USA.

Sisson J. W. (1982). Effects of soya-bean products on digestive processes in the gastrointestinal tract of preruminant calves. Proc. Nutr. Soc., 41, 53

Tacon, A.G.J., 1997. Fishmeal replacers: review of antinutrients within oilseeds and pulsesa limiting factor for the aquafeed Green Revolution? In: Tacon, A., Basurco, B. ŽEds.., Feeding Tomorrow's Fish. Proceedings of the Workshop of the CIHEAM Network on Technology of Aquaculture in the Mediterranean ŽTECAM., Jointly Organised by CIHEAM, FAO and IEO, 24-26 June 1996, Mazarron, Spain. CahiersOptions-Mediterraneennes, vol. 22, pp. 153-182.

Vasconcelos I. M., I. C. F. Brasil, J. T. A. Oliveira, C. C. Campello, F. M. M. Maia, M. V. M. Campello, D. F. Farias and A. F. U. Carvalho (2009). Combination of Chemical Analyses and Animal Feeding Trials as Reliable Procedures to Assess the Safety of Heat Processed Soybean Seeds. J. Agric. Food Chem. 57: 4668-4673 DOI: 10.1021/jf803903h Abstract

Woodworth J. C., M. D. Tokach, R. D. Goodband, J. L. Nelssen, P. R. O'Quinn, D. A. Knabe, and N. W. Said (2001). Apparent ileal digestibility of amino acids and the digestible and metabolizable energy content of dry extruded-expelled soybean meal and its effects on growth performance of pig. J. Anim. Sci. 79:1280-1287

Yin Y. L., Huang R. L., Zhong H. Y., Chen C. M., and Dai H. (1991). Influence of different cannulation techniques on the pre-cecal digestibility of protein, amino acids and cell wall constituents from diets, containing different protein meal, in pigs. Animal Feed Science and Technology 35:271-281

Yin Y. L., Huang R., and Zhong H. Y. (1993a). Comparison of the ileorectal anastomsis and conventional method for the measurement of ileal digestibility of protein sources and mixed diets in growing pigs. Animal Feed Science and Technology 42: 297-308

Yin Y. L., Zhong H. Y., Huang R. L., Chen C. M., Li T. J., and Pai Y. F. (1993b). Nutritive value of feedstuffs and diets for pigs. I. Chemical composition, apparent ileal and fecal digestibility. Animal Feed Science and Technology 44:127.

Yin Y. L. (1994). Nutritive value of feedstuffs and diets for pigs, II. Apparent post-ileal digestibility and interrelationship between dietary constituents and fecal and ileal digestibility. Animal Feed Science and Technology 45:243-255

Yin Y. L., Chen C. M., Zhong H. Y. and Huang R. L. (1994). Digestibility of energy, cell wall constituents, crude protein and amino acids of the Chinese oil seed meals for pigs. Animal Feed Science and Technology 45: 283-298 
Yin Y. L., Li T. J. and Huang R. L. (2008). Evaluating standardized ileal digestibility of amino acids in growing pigs. Animal feed Science and Technology 140:385-401 


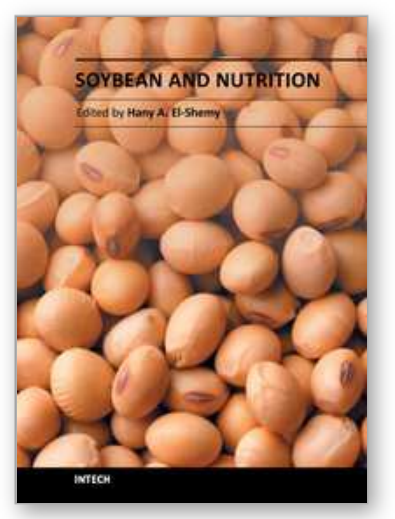

\author{
Soybean and Nutrition \\ Edited by Prof. Hany El-Shemy
}

ISBN 978-953-307-536-5

Hard cover, 476 pages

Publisher InTech

Published online 12, September, 2011

Published in print edition September, 2011

Worldwide, soybean seed proteins represent a major source of amino acids for human and animal nutrition. Soybean seeds are an important and economical source of protein in the diet of many developed and developing countries. Soy is a complete protein and soy-foods are rich in vitamins and minerals. Soybean protein provides all the essential amino acids in the amounts needed for human health. Recent research suggests that soy may also lower risk of prostate, colon and breast cancers as well as osteoporosis and other bone health problems and alleviate hot flashes associated with menopause. This volume is expected to be useful for student, researchers and public who are interested in soybean.

\title{
How to reference
}

In order to correctly reference this scholarly work, feel free to copy and paste the following:

Yulong Yin, Andrew A. Fatufe and Francois Blachier (2011). Soya Bean Meal and Its Extensive Use in Livestock Feeding and Nutrition, Soybean and Nutrition, Prof. Hany El-Shemy (Ed.), ISBN: 978-953-307-536-5, InTech, Available from: http://www.intechopen.com/books/soybean-and-nutrition/soya-bean-meal-and-itsextensive-use-in-livestock-feeding-and-nutrition

\section{INTECH}

open science | open minds

\section{InTech Europe}

University Campus STeP Ri Slavka Krautzeka 83/A 51000 Rijeka, Croatia

Phone: +385 (51) 770447

Fax: +385 (51) 686166 www.intechopen.com

\section{InTech China}

Unit 405, Office Block, Hotel Equatorial Shanghai No.65, Yan An Road (West), Shanghai, 200040, China 中国上海市延安西路65号上海国际贵都大饭店办公楼405单元 Phone: $+86-21-62489820$

Fax: +86-21-62489821 
(C) 2011 The Author(s). Licensee IntechOpen. This chapter is distributed under the terms of the Creative Commons Attribution-NonCommercialShareAlike-3.0 License, which permits use, distribution and reproduction for non-commercial purposes, provided the original is properly cited and derivative works building on this content are distributed under the same license. 